\title{
The environmental bioinorganic chemistry of aquatic microbial organisms
}

\author{
Martha Gledhill ${ }^{1 *}$, Christel S. Hassler ${ }^{2}$ and Veronique Schoemann ${ }^{3}$ \\ ${ }^{1}$ National Oceanography Centre, School of Ocean and Earth Science, University of Southampton, Southampton, UK \\ 2 Plant Functional Biology and Climate Change Cluster, University of Technology Sydney, Broadway, NSW, Australia \\ ${ }^{3}$ Department of Biological Oceanography, Royal Netherlands Institute for Sea Research, AB Den Burg, Texel, Netherlands \\ ${ }^{*}$ Correspondence: martha@soton.ac.uk \\ Edited by: \\ Bradley M. Tebo, Oregon Health \& Science University, USA \\ Reviewed by: \\ Bradley M. Tebo, Oregon Health \& Science University, USA
}

A few key inorganic elements, many of them metals, are essential for life. Approximately $40 \%$ of all proteins are metalloproteins which are at the center of the fundamental biological processes that drive biogeochemical cycles. Metalloproteins split water, acquire carbon, reduce carbon, and reoxidize carbon. They are also integral to the nitrogen and oxygen cycles.

In aquatic systems, metals are present at an extraordinarily wide range of concentrations from metal rich hydrothermal systems to the extremely metal poor Southern Ocean. Moreover, the relative abundance of metals to each other is not universal. Such differences are primarily a result of the metal source, input rate, and the major ion $(\mathrm{S}, \mathrm{O}, \mathrm{Cl})$ composition of their environment. Transition metals, in particular, exhibit diverse environmental behaviors and biological availability, with changes in oxidation state and affinity for nonmetals combining to create a rich chemistry and diversity of uses.

\section{REFERENCES}

Barnett, J. P., Millard, A., Ksibe, A., Scanlan, D. J., Schmid, R., and Blindauer, C. A. (2012). Mining genomes of cyanobacteria for elements of zinc homeostasis. Front. Microbiol. 3:142. doi: 10.3389/ fmicb.2012.00142

Boyd, E., Fecteau, K., Havig, J., Shock, E., and Peters, J. W. (2012). Modeling the habitat range of phototrophic microorganisms in Yellowstone National Park: toward the development of a comprehensive fitness landscape. Front. Microbiol. 3:221. doi: 10.3389/ fmicb.2012.00221

Cuss, C., and Gueguen, C. (2012). Impacts of microbial activity on the optical and copper-binding properties of leaf-litter leachate. Front. Microbiol. 3:166. doi: 10.3389/ fmicb.2012.00166

Desai, D. K., Desai, F., and Laroche, J. (2012). Factors influencing the diversity of iron uptake systems in aquatic microorganisms. Front. Microbiol. 3:362. doi: 10.3389/ fmicb.2012.00362

Glass, J., and Orphan, V. J. (2012). Trace metal requirements for microbial enzymes involved in the production and consumption of methane and nitrous oxide. Front. Microbiol. 3:61. doi: 10.3389/fmicb.2012. 00061

Gledhill, M., Devez, A., Highfield, A., Singleton, C., Achterberg, E. P., and Schroeder, D. (2012). Effect of metals on the lytic cycle of the coccolithovirus, EhV86. Front. Microbiol. 3:155. doi: 10.3389/ fmicb.2012.00155

Hassler, C., Sinoir, M., Clementson, L., and Butler, E. C. V. (2012). Exploring the link between micronutrients and phytoplankton in the Southern Ocean during the 2007 austral summer. Front. Microbiol. 3:202. doi: 10.3389/ fmicb.2012.00202

It is thus not surprising that this diversity results in a plethora of metal geomes and metal biomes, with organisms exploiting and altering their metallo-environments. A research topic exploring current research themes in environmental aquatic bioinorganic chemistry should thus incorporate articles on a diverse range of subjects. We have been honored to include both reviews and original research articles that taken together, reflect the interdisciplinary nature of the subject area and the diversity of geomes and biomes in which inorganic elements, particularly metals, play a fundamental role.

We have thus been able to include articles on metals, their speciation, and interactions with phytoplankton (Cuss and Gueguen, 2012; Hassler et al., 2012; Shaked and Lis, 2012; Sunda, 2012), on metal acquisition and use by microbes (Barnett et al., 2012; Desai et al., 2012; Glass and Orphan, 2012; Morrissey and Bowler, 2012; Nuester et al., 2012; Scheidegger et al., 2012) and on the effect of inorganic ions in the environment on organism interactions and community structure (Boyd et al., 2012; Gledhill et al., 2012).

Morrissey, J., and Bowler, C. (2012). Iron utilization in marine cyanobacteria and eukaryotic algae. Front. Microbiol. 3:43. doi: 10.3389/fmicb. 2012.00043

Nuester, J., Vogt, S., Newville, M., Kustka, A. B., and Twining, B. S. (2012). The unique biogeochemical signature of the marine diazotroph Trichodesmium. Front. Microbiol. 3:150. doi: 10.3389/ fmicb.2012.00150

Scheidegger, C., Suter, M. J.-F., Behra, R., and Sigg, L. (2012). Characterization of leadphytochelatin complexes by nano-electrospray ionization mass spectrometry. Front. Microbiol. 3:41. doi: 10.3389/fmicb.2012.00041

Shaked, Y., and Lis, H. (2012). Disassembling iron availability to phytoplankton. Front. Microbiol. 3:123. doi: 10.3389/ fmicb.2012.00123

Sunda, W. (2012). Feedback interactions between trace metal nutrients and phytoplankton in the ocean. Front. Microbiol. 3:204. doi: 10.3389/fmicb.2012.00204

Received: 28 March 2013; accepted: 08 April 2013; published online: 25 April 2013.

Citation: Gledhill M, Hassler CS and Schoemann V (2013) The environmental bioinorganic chemistry of aquatic microbial organisms. Front. Microbiol. 4:100. doi: 10.3389/fmicb.2013.00100

This article was submitted to Frontiers in Microbiological Chemistry, a specialty of Frontiers in Microbiology.

Copyright (C) 2013 Gledhill, Hassler and Schoemann. This is an openaccess article distributed under the terms of the Creative Commons Attribution License, which permits use, distribution and reproduction in other forums, provided the original authors and source are credited and subject to any copyright notices concerning any third-party graphics etc. 